\title{
Luxury in Germany: Sick Cars and Healthy Bodies
}

\author{
Brigitte Biehl $^{1}$
}

Accepted: 19 July 2021

(C) The Author(s) 2022

\begin{abstract}
The car is one of the few luxury items that historically is widely accepted in Germany, the land of "discreet consumption." This contribution draws on social science research, includes writings on popular culture, and presents examples from people and their cars in the media that give evidence of how luxury is increasingly emotionally charged, enriched, and negotiated. Cars were status symbols in Germany as a divided nation, with people in West Germany driving a Mercedes and people in the East driving a Trabant. Today, German rappers praise their "sick" cars, and paradox Bio Germans shield their luxury body in an expensive SUV. These examples illustrate luxury consumption that aesthetically and narratively links identities to cultural heritage. The media discourse reflects the symbolic and also the increasingly affective nature of luxury, while healthy "luxury" bodies remain in a competition for limited resources in a social context.
\end{abstract}

Keywords Car $\cdot$ German rap $\cdot$ Luxury $\cdot$ Mercedes $\cdot$ Popular culture $\cdot$ Trabant $\cdot$ SUV

\section{Introduction}

In Germany, luxury is often received with a mix of admiration, disgust, and suspicion. In this contribution, I discuss some antecedents and trends in the land of "discreet luxury" (Sack et al., 2015) with an emphasis on cars. A car is one of the few status symbols that historically is widely accepted in Germany and has always been embedded in conspicuous consumption (Veblen, 1899), which individuals engage in to publicly display their economic power, prestige, and status. Rappers today not only symbolically continue this tradition, but emotionally link to this form of cultural heritage (Boltanski and Esquerre, 2020: 18) and praise their "sick" cars that give evidence of their social success. For other consumers, expensive SUVs are not only a status symbol, but a vehicle to protect their healthy body from the outside world in line with a trend towards conscious consumption. People feed their "luxury body" with healthy, but unsustainable foods and shield it by wasteful SUVs.

To discuss these increasingly emotional developments of luxury in society, this article draws on social science

Brigitte Biehl

brigitte.biehl@srh.de

1 School of Popular Arts, SRH Berlin University of Applied Sciences, Potsdamer Str., 18810783 Berlin, Germany research and includes writings on popular culture which is worth studying because of its role in "shaping people's identities, in giving people ideas about what's good and bad, what's beautiful and ugly, [..] and so on" (Berger, 2020: 2). Television and the media critically look at privilege and wealth, in a German society that stands in a tradition of equality. On social media and in music however, the younger generation in particular openly present and praise their wealth. Popular culture shows how attitudes towards luxury persist, are challenged and continually negotiated, and also testifies of the enrichment economy (Boltanski and Esquerre, 2020: 42) with its emotional and affective experience of luxury consumption in addition to its social and symbolic function.

\section{Cars as Luxury Symbols in Germany}

The car has always been one of the most accepted status symbols in Germany. In 1886, the first Mercedes Benz hit the road and its legacy, along with the legacy of other German auto manufacturers, has continued ever since. Among the German automotive luxury brands are Porsche, Mercedes, BMW, Audi, and Maybach. In Germany, conspicuous consumption is not goal of all billionaires, while the new rich, the uppermiddle class, and rappers in particular like status symbols such as cars. 
Looking for luxury commonly means taking a look at the really wealthy people that commonly display their distinction through consumption (Veblen, 1899; Bourdieu, [1979]1984). Germany's billionaires however do not stand for a display of affluence and it is telling that there is not much bling to see. Among Germany's billionaires, Susanne Klatten (BMW) drives a Mini, a middle-class car, while other billionaires have been spotted on public transport in economy class, wearing off-the-rack suits (Oswald, 2014). Karl and Theo Albrecht (Aldi), Dieter Schwarz (Lidl), and the Klatten and Quandts (BMW) do not show off publicly, and the young billionaires seem to continue the tradition. For example, 18-year-old Kevin David Lehmann, who is one of the new entries into the Forbes billionaires list, and heir to the large retail health and beauty retailer 'dm'. It is difficult to find photos or other information about him, and he keeps his wealth hidden. The young man stands in a stark contrast to the American almostbillionaire Kendall Jenner, and to other rich teenagers who show-off private airplanes, watches, jewelry, cars, and champagne on Instagram (for example @ richrussiankids or \#RRK).

In Germany, the display of wealth and over-the-top consumption is still met with disapproval, envy, or an attitude that is critical of privilege or wealth. The German society that stands in a tradition of equality and the ideals of meritocracy (hard work should pay off), and there is some shared understanding in Germany that those who worked "hard and honestly" have "deserved" some luxury (Bach, 2013). In Germany (which became a republic after the First World War in 1918), people are still used to seeing aristocrats indulging in luxury, closely observed by the media (TV shows: Leute Heute, RTL Exklusiv, Prominent, magazines: Bunte, Gala, Goldenes Blatt), albeit commonly with an emphasis on the negative aspects of their existence.

The suspicious attitude also is reflected in other popular media. Television does not often show the super-rich "Dynasty" members (Das Erbe der Guldenburgs, 1980s, ZDF) and largely ignores their conspicuous consumption (Deutschlands große Clans, ZDF). Television presents millionaires with negative personality traits (Rivalen der Rennbahn) and elaborates on former millionaires that ended up in poverty (Promis auf Hartz IV). TV shows that celebrate money like other internationally successful shows have failed in Germany (Catch the Millionaire, PRO 7). While Germans do not want to see rich fellow Germans, they like to watch international wealth and luxury shows in TV or via streaming platforms (My Super Sweet Sixteen, Cribs, Real Housewives of Beverly Hills (and other franchises of the show), Selling Sunset). Among the few shows that are somewhat positive about the rich in Germany are Die Geissens, a wealthy couple who attract little envy due to their mostly unsophisticated behavior and looks. Heidi Klum's Germany's Next Topmodel is openly discussed in the media for the exploitative conditions for young women and the "fake glamour" it is trying to sell (Prokop et al., 2011).

The critical attitude of contemporary media phenomena can still be seen to reflect Max Weber's Protestant work ethic and other deep-seated beliefs that relate to Pietism which originated in Germany. This attitude rejects unnecessary spending and the desire for extravagance, foregrounding restraint and ethics. Germany also is seen as a less class-based society, given the development after the Second World War. Luxury in every country has its particular historic pedigree and economic story. A look back into the twentieth century history allows to tell the story with a focus on the persistent luxury item the car.

After the Second World War, Germany was divided into the Western part, the Bundesrepublik Deutschland (BRD), and the socialist German Democratic Republic (GDR or 'DDR' in German). In the German Democratic Republic (1945-1989), people who had a car drove one of only a few models (e.g., the Wartburg, Trabant or "Trabi”). Any car was seen as a luxury item (Roesler, 2005: 45) as the status of a luxury item typically depends on availability. Cars were rare. For example, a Trabant or Wartburg automobile sold for thousands of DDR-Mark with waiting times between 7 and 16 years (MDR, 2020). The situation with other luxury goods was similar. Western products (Milka chocolate, Levi's jeans) were sought for, and technical devices such as color TVs were rare and expensive. For example, a VCR-recorder was listed for 7350 DDR-Mark, which was half an average worker's annual income. Social distinction through consumption (Bourdieu, [1979]1984) did not have a place in the DDR "socialist workers' and peasants' state," which put first the satisfaction of material needs as a basis for people's physical and intellectual development (Roesler, 2005: 36). Food, clothing, and housing were cheap, but luxury items were incredibly expensive and very difficult to obtain. This historical pedigree is "in the DNA" of the nation and persists so that, today, people in Eastern Germany "need less money to be rich," and reject excessive spending (YouGov, 2019). Germans have experienced in many ways how luxury is relative to time and place, and how it always is affected by social change.

In the West, all classes benefitted from the economic upswing ("Wirtschaftswunder") in the 1950s and 1960s and people worked hard and improved their living conditions. The German Mercedes, today one of the world's leading luxury car manufacturers, has always been around on the streets as a classic yellow cab (Mercedes E-Klasse) or as a car for the rich (Mercedes S-Klasse) that was largely accepted as a symbol of the establishment that serves a status demarcation (Bourdieu, [1979]1984), but not always met with sympathy. In everyday language, a rejection of conspicuous consumption can be found, for example rich men driving their Mercedes were pejoratively called "Bonzen" (which has to do with motor fuel). Many teenagers and punks in subculture also felt 
attracted to the Mercedes, albeit in a different way, breaking off its emblematic star from the hood and adding it to their jewelry collection along with other decorative pendants such as decoded militaristic and historic symbols that were worn for provocation (Stiglegger, 2021: 105). The ambivalent pop cultural fascination continues today.

\section{Cars in Popular Culture}

The love for cars has proliferated into other social groups in Germany today. This includes German rappers, often with an immigrant background, who are sporting their Mercedes, Porsche, or similar cars that come polished, tuned, and with colored car wrappings (violet also works here!). Social media and video-on-demand proliferate their choices, adding to a global cacophony of luxury display with so many influencers showing their extravagant shopping, travels, and "spectacular reality-narrations" (Kleiner, 2018: 162). Consumption choices in these social groups strongly resonate Bourdieu ([1979]1984), when taste is a result of social class and environment, and not an individual, aesthetic choice. German rappers praise their cars in their song titles and they all focus on a clearly defined segment. Examples include Kianush's SUV; Fler's $A M G$; Kool Savas' $A M G$; Kurdo and Majoe's Maserati; Raf Camora's Maserati, and many more. GZUZ devotes an entire song to the Mercedes CL500. In this song, he acknowledges the fans' financial contribution:

Es ist vollbracht, Geld gut investiert. CL fünf hundert, $a b$ jetzt wird radiert. Frisch foliert und ich wollt nochmal Danke sagen/ An alle Fans da draußen, danke für den kranken Wagen. (It's done, money well invested. CL five hundred, we are rubbing (the street). Got fresh car wrapping and I wanted to thank all our fans again for this sick car.)

On Instagram, members of Hamburg's 187 Strassenbande articulate that "excessive cruising" (@gzuz187_official) is their favorite hobby, and post about "CaRPorN" (@maxwell187erz) (Figure 1). Rappers commonly draw on strongly masculine codes and symbols, and use the car as a vehicle to become "a man" (Süß, 2021). In their videos, camera shots of expensive vehicles alternate with misogynist "ass shots" of the half-naked bottom of a female model, objectifying women along with other status symbols (Süß and Kreß, 2021: 152). From a sociological perspective, self-selection into a social group of "rappers" is achieved here by the preferences on luxury cars, misogynist behavior, and a rejection of values shared by more educated members of German society.

Popular culture and social media provide a compelling aesthetic frame and reference point for the "habitus" (Bourdieu, 1977) that is acquired through imitation, colorfully illustrating the way that rappers perceive the social world around them and react to it. Popular music in particular generates powerful emotional responses through its lyrics, melody, and beat and

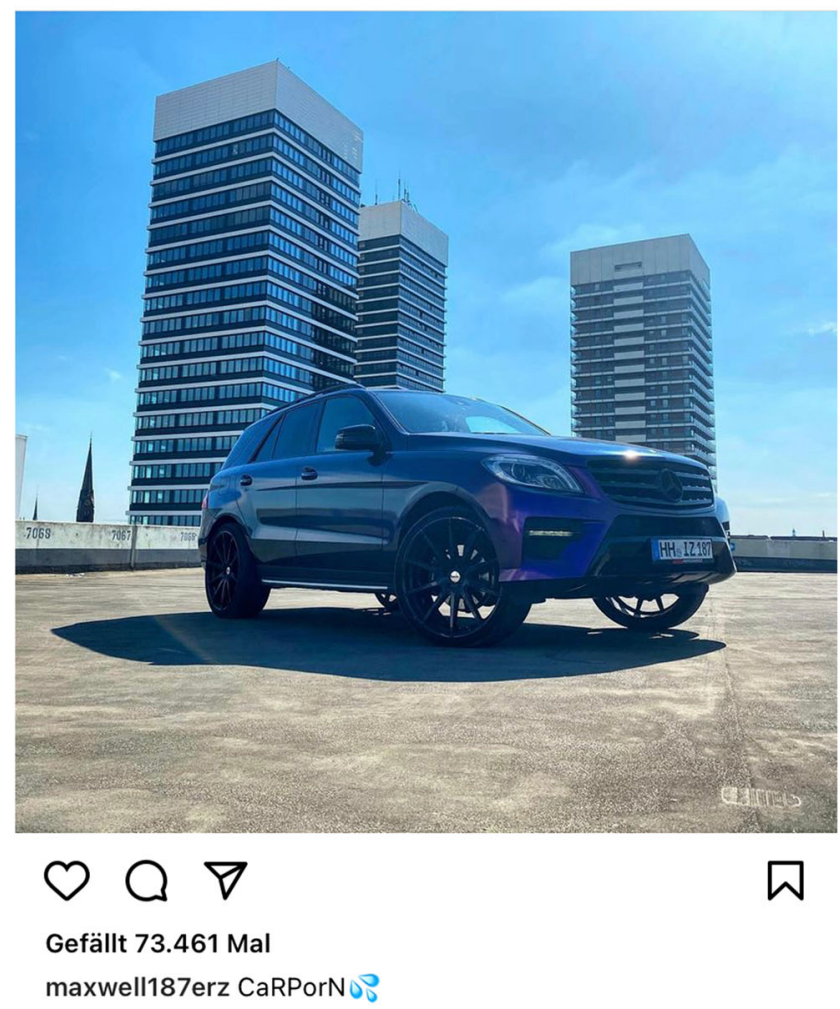

Fig. 1 Mercedes SUV, Instagram @ maxwell187erz, 6.8.2020, https:// www.instagram.com/p/CDjTRsgqigs/

may form a cultural imperative (Berger, 2020: 133). Music affects people and may "become a more dominant socializing influence on us than our parents and teachers" (Berger, 2020: 134). What can be seen in the rap discourse is that, in their longing for the luxurious life, rappers openly express what can be seen as an astonishingly conservative attitude, a strong work ethic from counter-culture, along the lines of "Rap hard, be rich!." German rapper and teen-idol Bushido aims to reach up high, coming from the proverbial street: "Vom Bordstein bis zur Skyline" ("From the road kerb up to the skyline"). Their music illustrates the influence of the reality in which individuals are socialized, when for example rapper Kool Savas often refers to his personal history of rejection by friends and family and how this has influenced his current attitude. For Kool Savas, "AMG" also means "an mich glauben" ("believe in myself"), and he values his reflection in the polished AMG car finish as a personal confirmation of success, while also demonstrating it to the others by "driving past" ("Jetzt roll' ich an ihnen vorbei, vorbei, vorbei, oh-ohoh, oh-oh-oh").

These examples illustrate the emotional and affective nature of luxury consumption that is more than a symbolic display of wealth, but a personal endeavor that links identities to 
forms of cultural heritage (Boltanski and Esquerre, 2020: 42). The Mercedes (AMG) is part of Germany's culture, similar to other famous German luxury brands that are sought for globally and also often have their roots in the European tradition of engineering and craftsmanship: Meissen, Villeroy \& Boch (bone china), Faber-Castell (stationery), Burmester (sound systems), Lürssen (shipbuilding), Rimowa (luggage manufacturer), Boss, Jil Sander, MCM (fashion), Glashütte, A. Lange \& Söhne, Montblanc (watches and accessories), Bulthaup, Poggenpohl (kitchen) (Hilpert, 2018). The Mercedes is frequently displayed by rappers with migrant family roots to show that they have not only made it, but succeeded in a German society that has not had faith in them, recreating their identity symbolically and affectively.

Culture is performed through aesthetic work (Biehl \& vom Lehn, 2016), and rappers and those who want to be like them in their "sick cars" cruise along famous shopping streets such as and Kurfürstendamm or "Ku'damm" (Berlin), Kaufingerstrasse and Maximilianstrasse (Munich), Jungfernstieg (Hamburg), Königsallee or "Kö" (Düsseldorf), and Goethestrasse (Frankfurt). However, not many locals often shop till they drop in these prominent tourist sites. In many cities, particularly in Berlin, for which the former Governing Mayor Klaus Wowereit created the slogan, "arm aber sexy," ("poor but sexy"), ordinary people cannot engage in luxury shopping. Many occupy low-wage jobs and simply do not have the budget.

Some of the groups who do not have sufficient financial capital still find ways to drive luxury cars, for example young migrant men, often with a Turkish background who became Germany's largest minority following work immigration in the 1960s. This is perceived with criticism and suspicion, and has also been explained by flexible financing and leasing opportunities - when a group pools the money and guys take turns driving (Frey, 2015). This phenomenon shows individuals' effort not to deviate from their social group. They try to attain the same dominant taste and social class markers that they see with their idols in the German rap scene, and be part of their story of success, even if this narrative enrichment (Boltanksi \& Esquerre, 2020: 112) comes at a high financial cost. Valuing the car which provides a sensual experience of driving or "cruising," and these young people also give evidence of the importance of the aesthetic and emotional nature of luxury.

In the Germany of today, luxury has been "democratized" and is broadly accessible to the many, as so-called masstige luxury, combining mass and prestige. Luxury is subjected to less moral critique than ever before, particularly by young consumers (Thieme, 2017: 9). People agree with the statement that luxury "is making life better" (Statista, 2020). However, on the broader level, young people in Germany have realized that a life of luxury is available only for relatively few people (Forsa, 2014). Poverty and wealth have solidified in Germany over the past decades, and rich circles have become closed and detached from the rest of society (Spannagel, 2016). Not only is luxury increasingly out of reach for many, but people's values are also changing. Again, this trend can be seen in cars, for example in the historic status symbol of a company car. Company cars commonly signal to the world a person's professional rank. Whether it's a Volkswagen, Audi, Mercedes, BMW or Porsche, the rule of thumb has long been, the more expensive the car, the higher up the employee is in the company's hierarchy. Today, for a mix of reasons ranging from increased health awareness, concern for the environment, and traffic congestion, more young professionals opt for rail cards, company bicycles, and car-sharing budgets (Blume, 2020).

This preference for an urban cycling style also can be seen reflected in pop culture - albeit again in a luxury version. South Korean DJ and influencer Peggy Gou, living in Berlin, promotes in an advertising video a bike by Louis Vuitton (2020). In the video, the camera follows her on a tour through Berlin on a red LV-marked bicycle. One of these luxury bikes that are produced in cooperation with Maison Tamboite in Paris cost around 22.000 Euros - which may explain why they are not normally spotted on the streets of Berlin Kreuzberg through which the model is cruising. Her performance of luxury and sparkle generally is received skeptically and labelled as "alien" and ill-fitting in the German capital (Hartmann, 2021). Berlin suffers from gentrification and sees itself rooted in an underground tradition of electronic music. This scene is kept alive through aesthetic cultural performances, where excess does not require spending much money on clothing and consumption, rather is embodied through an egalitarian, experience-oriented behavior in the spirit of techno as a counter-culture open for people from all classes (Biehl and vom Lehn, 2016). Economically, there is not so much money available to people in Berlin, as the country's highpaid jobs and inherited wealth have moved to the 'West' after the Second World War, i.e., can be found in Munich, Frankfurt am Main, Cologne or Düsseldorf, and in the historic trading city Hamburg.

\section{Bodies in Luxury Cars}

Cars are not only used to symbolize wealth, but are tied to emotional and personal issues. These are for example also promoted by German rappers, who use their Mercedes to take their kids on ski holidays in the mountains (Kool Savas' "AMG") that they themselves had not visited in their urban childhood. For many other musicians and professionals in the creative industries, a flexible life-style and self-fulfillment also is the primary motivation, but often at the cost of financial security when they do not become stars (Biehl, 2020). Many Germans acknowledge that not only material aspects and 
luxury goods make their life "rich," but health, family, and social contacts (Bundesregierung, 2021: 378). While health for example is influenced by wealth and income (Bundesregierung, 2021: 380), Germany's people follow a trend that is strong in today's Western luxury industry: conscious consumption and non-material values are "in," while big cars and fancy clothes "are out" (YouGov, 2020). The masses would agree with the statement "health is the new wealth" (Meurer, 2020), finding that what matters more than luxury goods is good health, free time, and well-being. This can be linked to more general developments, in which timeconsuming work in corporate structures has made place to boundaryless careers that value flexibility, and personal and family priorities (Tams and Arthur, 2010).

Showing-off status symbols is considered increasingly "uncool," as people are concerned about the environmental and social effects of wasteful consumption. This goes along with a political unease about the logic of liberal markets that further ecological crises and economic and political instability through the everyday practices of affluent (Western European) nations and their "imperial mode of living" (Brand and Wissen, 2017). In this climate, the brands that flourish are those that promise to treat well the environment, animals, and the consumer's body, for example in the area of "fair fashion" (Smend, 2020) or cosmetics (e.g., UND GRETEL, Figure 2).

The implication is that luxury is not "out," but has developed from being an external accessory ("Rolex") to something that is internalized into people's bodies. Luxury consumption today includes attempts to show social distinction via one's healthy "luxurious body." This phenomenon also can be seen in the exaggerated social media display of the aforementioned German rappers who not only present women with athletic bodies alongside sports cars, but present their own muscles and tattoos like prestige objects, their own masculine body as their symbolic capital. The transformation of luxury from an accessory into something that is internalized is also strongly visible internationally with influencers who promote cosmetic

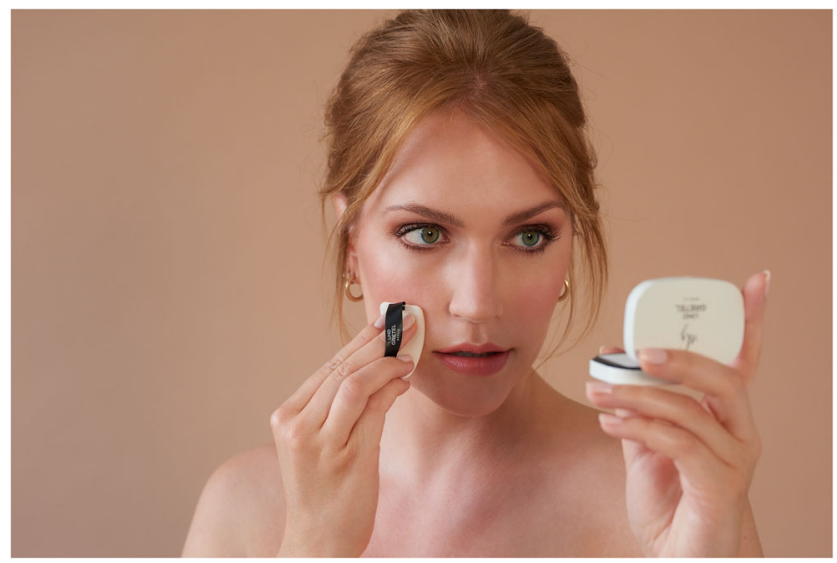

Fig. 2 UND GRETEL Organic Make-up, 2020 surgery, Botox, lip fillers, and all kinds of body enhancements, and engage in extensive and disciplined workouts (for example, members of the Kardashian family posting pictures from the gym, as German rappers and their followers do as well). This development, however, is not undisputed with a surge of another group of influencers who promote bodypositivity and alternative body displays (e.g., German influencer@natalie_stommel).

The trend of the luxury body can reinforce wasteful consumption. When many Germans, including "Bio-Germans" ("Bio-Deutsche") and millennials, try to reduce their meat consumption, some of the "healthy" food choices lead to the unsustainable transport of exotic super foods such as waterintensive avocados with a high carbon footprint. Among the avid consumers of organic, fair-trade, and biological foods and sustainability advocates are a large number of German SUV drivers (Steger, 2015). This appears paradoxical at first sight. There is a controversy around expensive, luxury SUVs that have gained popularity: they eat up a high number of resources, have high emissions, use and occupy large chunks of public space that is limited on Germany's roads and parking spaces, and entail a high accident risk for others (Brand and Wissen, 2017: 126). Criticism also soared after a number of SUV accidents shocked the public. For example, a Porsche Macan driver in Berlin collapsed behind the wheel, stepped on the gas, and killed four people. The Porsche SUV (Figure 2) turned into a killing machine because of its weight and engine power ("Bürgermeister von Berlin," 2019).

What seems paradoxical becomes rational however, when following a destructive logic that does not assume a broader social perspective. SUVs protect some individuals themselves and their healthy (wealthy) bodies, at high cost to others. This of course only works when the SUV is possessed by relatively few people. If everybody drove an SUV to avoid public transport and to shield themselves from the threatening world, the SUV's significance as a luxury item would be diminished and the standard of life for everyone in such a community would be lower (Brand and Wissen, 2017: 129). This development points to the social limits of growth in an affluent society, when it damages the quality of life through greater material quantity for a few (Hirsch, 1977).

\section{Concluding Thoughts}

Luxury has always expressed a longing for the "the good life," and practically has been used in the context of conspicuous consumption, when expensive goods are publicly displayed as symbols of economic power, prestige, and status (Veblen, 1899; Bourdieu, [1979]1984). Today, Germans seem to continue their history of discreet consumption, by putting an increasing emphasis on health as "the new wealth." Luxury is becoming internalized, but still mobilized in the context of 
conspicuous consumption when healthy bodies are displayed via new forms of social media and are shielded by expensive, unsustainable cars. Luxury is influenced by social classes and popular culture that works with emotions and may form strong cultural imperatives that affect people (Berger, 2020), also enriching items via narratives and stories that link to culture and heritage (Boltanski \& Esquerre, 2020). This contribution has presented some example of the media discourse to illustrate some of the emotional and affective fascination in luxury consumption that furthers the consumption of luxury items with regard to people's inner desires and their bodies, and goes beyond luxury consumption as a social and symbolic practice.

Luxury consumption, despite its affective nature, still is not an individual practice only, but has an influence on society and other people's wellbeing. Today's attitudes remain wasteful and egoistic (Steger, 2015) within an imperialist context (Brand \& Wissen, 2017). When luxury consumption particularly in late capitalism today is betting on heightening people's insatiable desires, instead of satisfying their needs for utilities (Böhme, 2017; Boltanksi \& Esquerre, 2020), the question arises of how the desires of some individuals for material and social distinction and health can be serviced, without making it impossible for others to satisfy even their basic needs. People in Germany increasingly reflect that luxury is structurally embedded in production, distribution, and consumption practices that provide jobs and economic growth, but also can be harmful to society and unsustainable. People in this country, which is one of the richest countries in the world, see a responsibility for their luxury and some have started to act on it, while popular culture, including rap music, television, and social media, gives evidence of this continuous struggle.

Acknowledgements I would like to thank Marcus S. Kleiner and Heidi Süß for their comments on German rappers, Wolfgang Til for his view on German TV, Rainer Erlinger for his thoughts on the German condition, and Tony McGuinness for his non-German perspective on the topic and the Mercedes key ring he once gave me.

Code Availability Not applicable.

Funding Open Access funding enabled and organized by Projekt DEAL.

Data Availability Not applicable.

\section{Declarations}

Conflict of Interest The author declares no competing interests.

Open Access This article is licensed under a Creative Commons Attribution 4.0 International License, which permits use, sharing, adaptation, distribution and reproduction in any medium or format, as long as you give appropriate credit to the original author(s) and the source, provide a link to the Creative Commons licence, and indicate if changes were made. The images or other third party material in this article are included in the article's Creative Commons licence, unless indicated otherwise in a credit line to the material. If material is not included in the article's Creative Commons licence and your intended use is not permitted by statutory regulation or exceeds the permitted use, you will need to obtain permission directly from the copyright holder. To view a copy of this licence, visit http://creativecommons.org/licenses/by/4.0/.

\section{References}

Bach, S. 2013. Reichtum statt Luxus besteuern. DIW Wochenbericht No. 6. https://www.diw.de/documents/publikationen/73/diw_01.c. 415349.de/13-6-3.pdf (accessed 10.8.2020)

Berger, A. A. 2020. USA Pop. Newcastle upon Tyne: Cambridge Scholars Publishing.

Biehl, B. 2020. Management in der Kreativwirtschaft. Grundlagen und Basiswissen. Wiesbaden: Springer.

Biehl, B. \& vom Lehn, D. 2016. Four-to-the-floor: The techno discourse and aesthetic work in Berlin. Society, 53(6), 608-613.

Bundesregierung 2021. Lebenslagen in Deutschland. Der Sechste Armuts- und Reichtumsbericht der Bundesregierung, draft version 22.3.2021 https://www.armuts-und-reichtumsbericht.de/ SharedDocs/Downloads/Berichte/entwurf-sechster-armutsreichttumsbericht.pdf?_blob=publicationFile \&v $=4$

Böhme, G. 2017. Critique of Aesthetic Capitalism. Berlin: Mimesis International.

Boltanski, L. \& Esquerre, A. 2020. Enrichment: A Critique of Commodities, transl. C. Porter. Cambridge: Polity.

Bourdieu, P. 1977. Outline of a Theory of Practice. Cambridge, MA: Cambridge University Press.

Bourdieu, P. [1979]1984. Distinction. A Social Critique of the Judgment of Taste, trans. R. Nice. Cambridge, MA: Harvard University Press.

Brand, U. \& Wissen, M. 2017. Imperiale Lebensweise. Zur Ausbeutung von Mensch und Natur im globalen Kapitalismus. Munich: oekom Verlag.

Bürgermeister von Berlin-Mitte kritisiert „panzerähnliche Autos“. 2019. Spiegel, 7. Sept. https://www.spiegel.de/panorama/gesellschaft/ berlin-unfall-mit-porsche-suv-kritik-an-panzeraehnlichen-autos-a1285743.html

Dederl, M., Kanitz, C. \& Mei-Pochtler, A. 2017. Vom Haben zum Sein die Zukunft der globalen Luxusindustrie. In Thieme, W. (Ed). Luxusmarkenmanagement, 147-161. Wiesbaden: Springer

Forsa. 2014. Der Weg ins Luxusleben. Survey by Westlotto. https:// www.isa-guide.de/isa-gaming/articles/120778.html (accessed 10.8. 2020)

Frey, P. 2015. Warum fahren junge Türken gerne teure Autos? Die Welt, 20.1. https://www.welt.de/motor/article136568529/Warum-fahrenjunge-Tuerken-gerne-teure-Autos.html (accessed 19.5.2021)

Hartmann, A. 2021. Das Schillern der Konkurrenz. taz. Die Tageszeitung, 17.3. https://taz.de/Das-Schillern-der-Konkurrenz/ !5754712/ (accessed 19.5.2021)

Hilpert A. 2018. Das sind die Top 50 der deutschen Luxusunternehmen. Businessinsider. https://www.businessinsider.de/wirtschaft/dassind-die-top-50-der-deutschen-luxusunternehmen-2018-8/ (accessed 10.8.2020)

Hirsch, F. 1977. The Social Limits to Growth. London: Routledge/ Kegan Paul.

Kleiner, M. 2018. Populäre Medienkulturen. Programmatische Positionen. Spiel, 4 (1), 147-186.

MDR. 2020. DDR-Automarkt in den 1970er-Jahren. Der Mangel wird verwaltet. https://www.mdr.de/zeitreise/stoebern/damals/ artikel106566.html (accessed 10.8.2020) 
Louis Vuitton 2020. A Mile in Peggy Gou's Shoes. https://www.youtube. com/watch?v=z1MkXI2d3f4 (accessed 10.5.2021)

Meurer, J. 2020. Health is the new wealth. Keylens/Inlux Neo-Luxury Studie 2025. https://www.keylens.com/health-is-the-new-wealth/ (accessed 10.8.2020)

Oswald, A. 2014. Das Leben der Milliardäre in Deutschland. Tagesspiegel https://www.tagesspiegel.de/politik/superreicheohne-protz-das-leben-der-milliardaere-in-deutschland/10342282. html (accessed 10.8.2020)

Prokop, U., Friese, N., \& Stach, A. 2011. Geiles Leben, falscher Glamour: Beschreibungen, Analysen, Kritiken zu Germany's Next Topmodel. Marburg: Tectum.

Blume, J. 2020. A Status Symbol Loses its Luster, Handelsblatt https:// www.handelsblatt.com/english/companies/company-cars-a-statussymbol-loses-its-luster/23540036.html?ticket=ST-8195538 ZW5eIemsp0cecsz70hUj-ap5 (accessed 10.5.2021)

Roesler, J. 2005. Massenkonsum in der DDR: zwischen egalitärem Anspruch, Herrschaftslegitimation und exquisiter Individualisierung. PROKLA. Zeitschrift für kritische Sozialwissenschaft, 35(138), 35-52.

Sack, A., Strohmaier, B., \& Parkin, C. 2015. Wie wir lernten, das Exklusive zu lieben - Was die Deutschen über Luxus denken, Welt am Sonntag, 25.10.2015, No. 43, S. 2-3.

Smend, M. 2020. Nachhaltige Modelabels: Die VOGUE-Auswahl für Sustainable Fashion. https://www.vogue.de/mode/mode-news/ nachhaltige-mode-labels?amp (accessed 10.8.2020)

Spannagel, D. 2016. Dauerhafte Armut und verfestigter Reichtum. WSIVerteilungsbericht 2018. Düsseldorf: Hans-Böckler-Stiftung.

Statista. 2020. Umfrage in Deutschland zu schönem Leben durch Luxus bis 2019. https:/de.statista.com/statistik/daten/studie/172153/ umfrage/meinung-kauf-teurer-sachen-da-luxus-das-leben-schoenermacht/ (accessed 10.8.2020)

Steger, J. 2015. Werden so viele SUV verkauft? Absatzwirtschaft https:// www.absatzwirtschaft.de/werden-so-viele-suv-verkauft-70561/ (accessed 10.8.2020)

Stiglegger, M. 2021. Schwarz. Die dunkle Seite der Popkultur. Kassel: Martin Schmitz Verlag.
Süß, H. 2021. Eine Szene im Wandel? Rap-Männlichkeiten zwischen Tradition und Transformation. Frankfurt: Campus.

Süß, H. \& Kreß, B. 2021. German Rap - A Changing Cultural Field From a Gender Studies Perspective. In Gonçalves, S. \& Majhanovich, S. (eds.) Art in Diverse Social Settings, 143-154. Bingley: Emerald Publishing.

Tams, S., \& Arthur, M. B. 2010. New directions for boundaryless careers: Agency and interdependence in a changing world. Journal of Organizational Behavior 31(5): 629-646.

Thieme, W. 2017. Das Wesen der Luxusmarke. In Luxusmarkenmanagement. Grundlagen, Strategien und praktische Umsetzung, 3-33. Wiesbaden: Springer.

Veblen, T. 1899. The Theory of the Leisure Class: An Economic Theory of Institutions. New York: Macmillan.

YouGov. 2019. Im Osten braucht's weniger, um reich zu sein. Survey by Europjackpot. http://presse.eurojackpot.de/wp-content/uploads/ 2019/11/191106_Presseinformation_Reichtum_Regionen.pdf (accessed 10.8.2020)

YouGov. 2020. Familie, Freunde und Sparen sind in. Aktuelle Umfrage zu Corona zeigt: Luxus wird neu definiert. Study by Europjackpot http://presse.eurojackpot.de/wp-content/uploads/2020/07/200721_ PM_Umfrage_Corona-mit-Grafik.pdf (accessed 10.8.2020)

Publisher's Note Springer Nature remains neutral with regard to jurisdictional claims in published maps and institutional affiliations.

Brigitte Biehl (PhD) is Professor for Media and Communication Management in the School of Popular Arts, SRH Berlin University of Applied Sciences, Germany. She has widely published on aesthetics, marketing, and consumption, and explores creative approaches to management and the influence of popular culture. Her latest books are Management in der Kreativwirtschaft (Springer, 2020) and Leadership in Game of Thrones (Palgrave, 2021). 